\title{
Urinary Biomarkers of Mycotoxin Induced Nephrotoxicity- Current Status and Expected Future Trends
}

\author{
Zsolt Ráduly ${ }^{1,2, *(\mathbb{D}}$, Robert G. Price ${ }^{3} \mathbb{0}$, Mark E. C. Dockrel1 ${ }^{4}$, László Csernoch ${ }^{2} \mathbb{D}$ and István Pócsi ${ }^{5}$ \\ 1 Doctoral School of Molecular Medicine, University of Debrecen, H-4032 Debrecen, Hungary \\ 2 Department of Physiology, Faculty of Medicine, University of Debrecen, H-4032 Debrecen, Hungary; \\ csl@edu.unideb.hu \\ 3 Department of Nutrition, Franklin-Wilkins Building, King's College, 150 Stamford St., London SE1 9NH, UK; \\ robert.price@kcl.ac.uk \\ 4 South West Thames Institute for Renal Research, Carshalton, Surrey SM5 1AA, UK; mark.dockrell@nhs.net \\ 5 Department of Molecular Biotechnology and Microbiology, Faculty of Science and Technology, \\ University of Debrecen, H-4032 Debrecen, Hungary; pocsi.istvan@science.unideb.hu \\ * Correspondence: raduly.zsolt@med.unideb.hu
}

check for

updates

Citation: Ráduly, Z.; Price, R.G.; Dockrell, M.E.C.; Csernoch, L.; Pócsi, I. Urinary Biomarkers of Mycotoxin Induced Nephrotoxicity-Current Status and Expected Future Trends. Toxins 2021, 13, 848. https://doi.org/ $10.3390 /$ toxins 13120848

Received: 11 October 2021

Accepted: 24 November 2021

Published: 28 November 2021

Publisher's Note: MDPI stays neutral with regard to jurisdictional claims in published maps and institutional affiliations.

\begin{abstract}
The intensifying world-wide spread of mycotoxigenic fungal species has increased the possibility of mycotoxin contamination in animal feed and the human food chain. Growing evidence shows the deleterious toxicological effects of mycotoxins from infants to adults, while large population-based screening programs are often missing to identify affected individuals. The kidney functions as the major excretory system, which makes it particularly vulnerable to nephrotoxic injury. However, few studies have attempted to screen for kidney injury biomarkers in large, mycotoxinexposed populations. As a result, there is an urgent need to screen them with sensitive biomarkers for potential nephrotoxicity. Although a plethora of biomarkers have been tested to estimate the harmful effects of a wide spectrum of toxicants, $\beta_{2}$-microglobulin $\left(\beta_{2}-\mathrm{MG}\right)$ and $N$-acetyl- $\beta$-D-glucosaminidase (NAG) are currently the dominant biomarkers employed routinely in environmental toxicology research. Nevertheless, kidney injury molecule 1 (KIM-1) and neutrophil gelatinase-associated lipocalin (NGAL) are also emerging as useful and informative markers to reveal mycotoxin induced nephrotoxicity. In this opinion article we consider the nephrotoxic effects of mycotoxins, the biomarkers available to detect and quantify the kidney injuries caused by them, and to recommend biomarkers to screen mycotoxin-exposed populations for renal damage.
\end{abstract}

Keywords: nephrotoxicity; mycotoxin; biomarkers; AKI; NAG; KIM-1; ochratoxin A; citrinin; NGAL

Key Contribution: The current procedures used to monitor exposure to mycotoxins are summarized and their importance emphasized in the light of the northward movement of mycotoxin producing microfungi. The value of extending monitoring to include urinary enzyme assays widely used in other fields is emphasized.

\section{Introduction}

The kidney is a multifunctional organ, the structural and functional unit of which is the nephron. The nephron consists of a variety of different cells which perform highly complex and precisely orchestrated physiological processes. Any stimuli which disturb these cells, and their interplay may induce kidney damage and subsequent endocrine dysfunction, cardiovascular disease, metabolic disorders, and further renal failure. The kidney is particularly susceptible to nephrotoxic attack, owing to its high blood flow and specialized metabolism. Environmental pollutants which target the kidney include metals, solvents and naturally occurring compounds, including aristolochic acid and mycotoxins [1]. Fungi or molds grow on a variety of foodstuffs including cereals, nuts, and fruit. Mycotoxins are naturally occurring toxic compounds produced by a wide spectrum 
of different microfungi. More than 500 mycotoxins have been identified, but few of them normally occur in the human diet in significant amounts and, consequently, affect human and animal health [2,3]. Oral exposure via contaminated food or feed is considered the predominant exposure route and represents a serious health issue. Low or moderate mycotoxin exposure over years can result in large economic loss and severe health effects in animals and man [4].

As the majority of transport processes involving nephrotoxic compounds or their derivatives occurs via the renal glomeruli and the proximal tubules, these are the main targets for xenobiotics, including mycotoxins [1,5]. Significant efforts have gone into studying those biomarkers, which could indicate the locus of the affected cells, furthermore, microRNA in the urine, assessment of exosomes and other extracellular vesicles are in focus as well [1]. As an example, microfungi and heavy metals can induce renal cell apoptosis, where both intrinsic and extrinsic cell death signaling pathways are involved. Much of the available experimental data has not yet been translated into robust accepted in vitro or ex vivo models to study nephrotoxicity in man. Furthermore, the growing body of evidence on the versatile nephrotoxic effects of various fungal secondary metabolites warns us that we still have a long way to go in the development and implementation of suitable diagnostic and therapeutic approaches with which to screen for the deleterious effects of these compounds $[1,5]$. To estimate the renal damages caused by nephrotoxic mycotoxins, a wide array of urinary biomarkers should be tested (Figure 1). In mycotoxin research field "biomarker" refers to the direct measurement of the excreted mycotoxin or a breakdown product [6]. This provides information on the degree of exposure, but no information on the adverse cellular or organ effects. To date, few studies have used urinary enzymes or kidney injury biomarkers to monitor the nephrotic effect of a mycotoxin. An early study of the effect of ochratoxin $\mathrm{A}$ in rats is promising but equivalent studies in humans are still lacking [7].

\section{Proximal tubule}

a1-Microglobulin
Kim-1
GST- $\alpha$
Cystatin C
NGAL

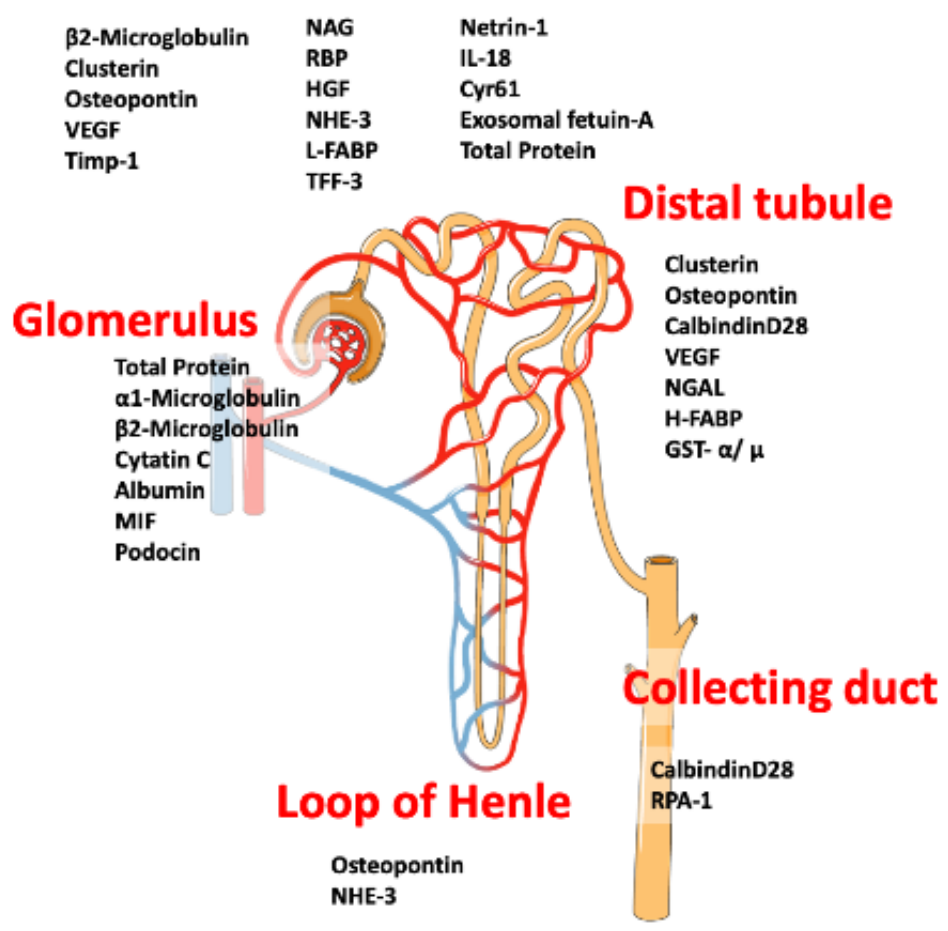

Figure 1. Biomarkers used to assess renal damage on the different sections of the nephron. Several putative urinary biomarkers are shown. Some of them are under study while other are well established. Modified from [8]. 


\section{Mycotoxin Exposure}

As a result of world-wide climate changes, mycotoxigenic microscopic fungi are spreading rapidly, imposing serious health risks on both household animals and consumers causing major economic losses [9-12]. The major mycotoxin producer microfungi belong to the genera Aspergillus, Fusarium and Penicillium. Their highly toxic secondary metabolites have carcinogenic, genotoxic, teratogenic, neurotoxic, hepatotoxic, nephrotoxic as well as with immune and endocrine systems disturbing properties [9-12]. Although mycotoxin contaminants typically represent a major threat to populations living in tropical regions [12,13], the boundaries of high-risk zones is moving north in the northern hemisphere [12]. Mycotoxins represent one of the major environmental toxicants threatening human health today. Exposure can be via food consumption, inhalation, dermal contact or through occupational exposure $[6,14,15]$. The most prevalent toxins in the food chain are: aflatoxins (AFs), ochratoxin A (OTA), patulin (PAT), fumonisins, citrinin (CIT), ergot alkaloids, trichothecenes like deoxynivalenol (DON), T-2 toxin (T-2) and zearalenone (ZEN) [16]. Because of the growing concern about mycotoxin-associated health problems including kidney injury, a search for suitable markers to quantify mycotoxin toxicity is urgently required. The most predominant exposure is to OTA and CIT, current methods for detecting exposure include just the determination of urinary levels of mycotoxins and/or their excreted forms [6,17-19]. As mycotoxins are naturally occurring secondary metabolites are often consumed by people, the exact nephrotoxic mechanisms should be clarified as well.

Ochratoxins are produced by Aspergillus ochraceus, Aspergillus carbonarius, and Aspergillus niger, which have a world-wide distribution and OTA can be found in a wide variety of agricultural products, including cereals, grapes, oil seeds, wine, and barley. According to the WHO guidance, the PTWI (provisional tolerable weekly intake) of OTA is $112 \mathrm{ng} / \mathrm{kg}$ body weight (bw) [20]. OTA has been classified by the International Agency for Research on Cancer (IARC) as a group 2B human carcinogen [19,21,22]. After biotransformation in the human body, more than 20 OTA derivatives have been described to date. OTA forms covalent DNA adducts through free radical and benzoquinone intermediates, moreover the OTA hydroquinone (OTHQ) metabolite can undergo an autoxidative process to generate the quinone electrophile OTA quinone (OTQ) that also reacts with DNA. Therefore, the formation of OTQ or phenoxy and aryl radicals can result in increased Reactive Oxygen Species (ROS) production that is mainly responsible for its cytotoxicity [12]. Possible mechanisms leading to OTA nephrotoxicity as well as its known hepatotoxicity and immunotoxicity may be linked to the inhibition of protein synthesis and lipoperoxidation. The modulation of the MAP kinase cascade has been reported in some cases as well $[20,23,24]$. OTA binds strongly to albumin, so its elimination by glomerular filtration is negligible. Instead, tubular secretion is the main excretion mechanism in kidney, and the tubular reabsorption could be partially responsible for intracellular accumulation of OTA [25]. Organic anion transporters (OATs) are membrane transport proteins and can play a role in transport processes of OTA. The basolateral OATs (OAT1 and OAT3) are mainly responsible for the uptake from blood into the tubular kidney cells, the apical OAT4 transporter may have a role in urinary reabsorption of OTA, resulting in its accumulation in the kidney [26].

As CIT often co-occurs with OTA and they are often analyzed together. According to the classification of IARC, CIT is a group 3 human carcinogen and is not classified in terms of its carcinogenicity in humans [21,27]. CIT has a "level of no concern for nephrotoxicity" (a provisional tolerable daily intake- "PTDI") value of $0.2 \mu \mathrm{g} / \mathrm{kg}$ bw. It is produced by several species in the genera Monascus, Aspergillus and Penicillium, and it occurs principally in plant products and stored grains $[28,29]$. CIT and OTA have also been associated with alterations in renal function and/or with the development of renal pathologies [30]. However, because of the shortage of available data, several questions have emerged, as outlined in the Balkan Endemic Nephropathy (BEN) report. Although the exact toxicity of CIT are not fully understood, CIT might exerts its toxic effect by altering 
mitochondrial function and it $\mathrm{Ca}^{2+}$ homeostasis [28]. It has also been reported that CIT treatment resulted in swollen and degenerated mitochondria in renal cortical cells of pigs, broiler chickens and laying hens as well [31]. Furthermore, it interferes with the electron transport chain, which results in oxidative stress, CIT also interferes with cholesterol and triglyceride metabolism. Acute intoxication is rare and appears mainly in feed, a small amount of data is available with the adverse effects of long term CIT intake [29]. While CIT has been reported as a non-mutagenic mycotoxin, some authors have pointed out that it can cause chromosomal abnormalities in bone marrow cells of mammals [28]. Coexposure to CIT and OTA simultaneously modifies DNA adduct formation with increasing appearance of the C-C8dG-OTA adduct [32]. Recently, several studies have been carried out with other mycotoxins as well. Kidney cell exposure to ZEN increased caspase-3 activity, malondialdehyde (MDA, a lipid peroxidation product) concentrations. IL-10, IL-6, TNF-alpha, Bax mRNA levels are decreased together with total antioxidant activity and down-regulated expression of GSH-Px, CAT and BCL-2 mRNA [33].

PAT is a water soluble, colorless, polyketide lactone, which is thought to exert its toxicity through reacting with thiol groups (cysteine, glutathione, thiol moieties of proteins) in the cytoplasm [34]. A recent study demonstrated p53 activation contributes to patulininduced nephrotoxicity via modulation of ROS generation [35].

Fumonisins are structurally similar to cellular sphingolipids and they have been shown to inhibit sphingolipid biosynthesis at ceramide synthase [36]. The primary amino and tricarballylic acid groups of the toxin are responsible for the reaction with ceramide synthase. Fumonisin-induced toxicity often results in apoptosis, alteration in cytokine expression or generation of oxidative stress [37]. IARC has classified fumonisin B1 (FB1) in toxicity group $2 \mathrm{~B}$ as probably carcinogenic [21].

Although the acute oral toxicity of sterigmatocystin (STC) is not well described, the main target organs in humans are the kidney and liver [17]. At doses between 10 and $100 \mathrm{mg} / \mathrm{kg}$ body weight, STC causes hyaline casts in the collecting tubules, pyknotic nuclei in the tubular cells at the cortico-medullary junctions as well as cortical hemorrhage. Hyaline degeneration or necrosis of tubular epithelial cells were detectable as well. At higher doses in the range of 100-144 mg/ $\mathrm{kg}$ body weight, lesions were accompanied by degeneration and necrosis of glomeruli with hyaline thickening of the basement membrane. Massive hemorrhage and necrosis are also seen when the dose was greater $144 \mathrm{mg} \mathrm{STC} / \mathrm{kg}$ body weight [38].

More than 20 types of aflatoxins (AFs) have been identified to date, and of these AFB1, AFB2, AFG1 and AFG2 have proved to be the most toxic to both humans and livestock. As a consequence, IARC has classified these mycotoxins as group 1 carcinogen, which means that they are carcinogenic to humans [39-41]. The consumption of high amount of AFB1 leads to aflatoxicosis, which is a serious and emerging problem in the world. Although AF-related notifications in food and feed, based on the European Union (EU) Rapid Alert System for Food and Feed (RASFF) is working well, similar methods should be introduced in developing countries as well [12,41,42]. Oxidative damage in a tissue is often caused by AFs, when ROS, e.g., hydrogen peroxide, hydroxyl radicals, superoxide radicals are generated. Their levels are often exceed the antioxidant capacity of the cells or they decrease the level of the defense mechanisms. Epidemiological surveys and studies have described various kidney and liver disorders within AFs- affected populations [42]. As AFs are among the most dangerous and best studied mycotoxins, a considerable amount of literature and experimental data are available, including urinary and fecal excretions of different AF metabolites [43,44].

The mycotoxins discussed above are listed in Table 1. The nephron segments affected, and doses studies are summarized. For brevity, Table 1 contains only a selection of the relevant literature to demonstrate the connection between nephrotoxicity and mycotoxins. 
Table 1. Mycotoxins with established nephrotoxic effects.

\begin{tabular}{|c|c|c|c|c|}
\hline Mycotoxin & Model System & Doses & Nephron Segment Involved & References \\
\hline Ochratoxin A & mice, monkey, human & over $10 \mathrm{ng} / \mathrm{kg}$ bw & proximal tubules & [45] \\
\hline Citrinin & mice, rabbit & 35-200 mg/kg bw & proximal tubules & [28] \\
\hline Zearalenone & mice & $40 \mathrm{mg} / \mathrm{kg}$ bw & $\begin{array}{l}\text { general kidney damage, not } \\
\text { characterized }\end{array}$ & {$[33]$} \\
\hline Fumonisin B1 & quail chicks & $200 \mathrm{ppm}$ & $\begin{array}{l}\text { proximal tubules, proximal } \\
\text { convoluted tubules }\end{array}$ & [46] \\
\hline Sterigmatocystin & mice, monkey & $10-144 \mathrm{mg} / \mathrm{kg}$ bw & collecting ducts & {$[38]$} \\
\hline Aflatoxin B1 & mice & 30-200 $\mu \mathrm{g} / \mathrm{kg}$ bw & $\begin{array}{l}\text { proximal tubule and general } \\
\text { kidney damage }\end{array}$ & {$[42,47]$} \\
\hline
\end{tabular}

The primary source of mycotoxin exposures for humans is dietary intake and, importantly, foods typically contain a versatile and hardly predictable mixture of mycotoxins rather than a sole mycotoxin contaminant $[27,48,49]$. There are three different ways for mixed mycotoxin contaminations to occur in food. Firstly, many fungal species are capable of producing a wide spectrum of different toxins, secondly food can be contaminated by more than one type of mycotoxin producer microfungi and thirdly diets are mixtures and could contain several different mycotoxin contaminants. Each of these routes can be harmful for the consumer. All of these mycotoxins are typically metabolized in the liver and are excreted via the kidneys, causing severe injuries and abnormalities in these organs $[5,17,20,28,50]$.

Although CIT and OTA are rarely produced by the same species, Penicillium verrucosum Dierckx is actually a good exception, which does produce both OTA and CIT, which considerably contributes to the mycotoxin content of cereals in cool temperature climates. Nevertheless, OTA is the main toxin and CIT is produced in smaller quantities [51]. Furthermore, an A. niger strain was isolated from maize in Portugal, which was able to produce fumonisins and OTA at the same time [51]. As a consequence of global trading and transportation of goods, cereals, grapes, fruits and nuts are susceptible to contamination [51-53] and, because human diet is a complex mixture of various ingredients, multiple mycotoxicosis is a rising problem world-wide [48,54]. Although the most affected regions are still in low GDP Third World countries [11,12], the mycotoxigenic fungal species preferring warm climates are currently moving northwards [12], a result of climate change. Not surprisingly, co-occurrence of mycotoxins in food and animal feed is a severe problem not just in Africa, but also in Europe [55].

As mentioned above, CIT is mainly produced by the genera Penicillium and Monascus, while the genera Pencillium and Aspergillus are the main OTA producers $[27,28]$. Concomitantly, increased OTA and CIT concentrations in food can increase the prevalence of tubuleinterstitial nephropathy [27]. A study on HK-2 cells (human proximal tubule-derived epithelial cells) revealed, that physiological relevant OTA and CIT can act synergistically, furthermore prolonged exposure could result in chronic kidney disease and tubulointerstitial fibrosis. These features can cause complete renal failure, particularly in vulnerable individuals $[27,51]$.

Although several investigations have been carried out to describe and explain the toxicological events elicited by combined mycotoxin exposures $[27,56,57]$, and the number of on-going research projects is rapidly increasing in this field, it would be basically important now to define new safe intake limits for mycotoxin combinations. Furthermore, it would be useful to monitor the physiological conditions including renal functions of people exposed to mycotoxin mixtures [12].

It is encouraging that a recent study in UK of children by Gratz et al. (2020) investigated multi-mycotoxin exposure and found that the principal source of mycotoxins was cereal foods. As breakfast cereal is liked and often consumed by children, their mycotoxin 
exposure is even higher than the more resistant adults. In this study, spot urine samples were analyzed for multi-mycotoxins using liquid chromatography-coupled tandem mass spectrometry [58].

Mycotoxicosis can occur at every stages of life in both humans and livestock, although the earlier the exposure, the more severe the long-lasting toxicological consequences $[12,31,59,60]$. As a result, WHO has recommended lower PMTDI limits in baby and child food, while in EU countries these limits are under strict control as well [61,62]. Importantly, adverse pregnancy outcomes, like abnormally lower body weight, neonatal jaundice, eclampsia, small head size or stillbirth may occur frequently in cases where high-level maternal mycotoxin exposure had occurred [63]. Although the complexity of placenta can protect the embryo and the fetus during intrauterine life, the mycotoxin exposure may contribute to several developmental disorders, even affecting the kidneys A recent study revealed that pregnant women are often exposed to combined effects of OTA and CIT [56], which may affect kidney development as well. In utero renal development in man continues up to birth with peak growth during the third trimester. Consequently, preterm and low birthweight infants tend to have a reduced nephron number [64]. Low nephron number, in turn, results in a significantly greater vulnerability to acute and chronic kidney damage [65].

After birth, infants are mainly dependent on their mothers in terms of nutrition and the most suitable nutrient for them is breast milk. Breastfeeding is more critical in those countries where the infant formulas are not available [66]. Breast milk provides developmental and psychological advantages to infants, although it could be even harmful if toxic agents, like mycotoxins, are secreted into breastmilk [66,67]. Interestingly, the colostrum may contain more OTA than the mature milk, so the severity of OTA exposures in infants could even be worse than those found for 4-6-month-old children [68].

The deleterious effects of mycotoxin exposure on renal functions of infants and children should therefore be investigated from as early as the neonatal period and should be considered separately from adults [69]. The occurrence of AKI may be frequent in even young age cohorts gives rise to two questions: firstly-how does mycotoxin toxicity affect the health of exposed patients and how best can any pathological changes in renal function be detected and quantified [70-73].

\section{Currently Available Methods to Detect Nephrotoxic Effects of Mycotoxins}

Biomonitoring studies have provided us with a better understanding of the extent of mycotoxin exposures in an affected population [74]. Recent research has focused mainly on the metabolites which are produced via biotransformation after mycotoxin consumption $[20,73,74]$. Typically blood or urine samples are analyzed and different analytical techniques have been developed to quantify and detect individual mycotoxins and their derivatives $[9,19]$. It is noteworthy, that there is an increase in studies dealing with breast milk as a biological matrix to information about the carry over rate of mycotoxins from food $[60,66,73,75]$. Although the available human toxicokinetic data is constantly increasing, the concentration of a metabolite is difficult to relate to clinical or pathological changes in affected individuals. Currently, studies are focusing on sensitive groups, e.g., pregnant women, infants or children, to avoid mycotoxicosis as early as possible $[56,60,63,67,76,77]$.

Although it is really difficult to monitor the exact consumption of mycotoxin-contaminated food [78,79], a seasonal and regional difference in OTA exposure was found in a study carried out in Bangladesh [78]. While OTA is found worldwide, it is a particular problem in Mediterranean countries, including Italy, Spain, and Greece [80-83], as well as several African countries, e.g., Cameroon, Senegal, Benin, and Nigeria [84,85]. In order to assess OTA exposure, urine and blood are analyzed together with its intake via food and from air. Interpretation of OTA exposure is currently difficult due to the lack of specific and validated biomarkers and detailed toxicokinetic.

CIT occurs mainly in plant products and stored grains as a consequence of Penicillium and Aspergillus infestation. Unfortunately, Monascus fermentation products, like red mold rice, used as food supplements, may also contain CIT. Recently, a new EC Commission 
Regulation has been published (EU 2019/1901) amending Regulation (EC) No 1881/2006. The maximum level of CIT in food supplements is lowered from $2000 \mu \mathrm{g} / \mathrm{kg}$ to $100 \mu \mathrm{g} / \mathrm{kg}$, based on rice fermented with "red yeast" Monascus purpureus [86]. Biomonitoring studies have been carried out in Germany, the Czech Republic, and Bangladesh; however, the results could be improved if larger CIT affected areas were included [87]. The appearance of CIT and its metabolite, dihydro-citrinone (DH-CIT) has frequently been monitored in urine, however, the correlation with renal failure has not been established yet. Recent publications have reported, that the co-occurrence of mycotoxins (e.g., FB1, CIT, ZEN) can be more dangerous to health than the exposure to a single mycotoxin $[51,88-90]$. It is noteworthy that both cell culture and histological kidney model systems are currently available to test the renal toxicity of environmental toxicants, including mycotoxins. Hence, it is relatively easy to test for any deleterious effects and propose mechanisms of actions in vivo [91]. Although tracking mycotoxins and metabolites in body fluids and excreta could give a good picture about their intake, transformation, and secretion, less is known of their toxicological effect in vivo. In order to clarify the nephrotoxic effects of different mycotoxins and their derivatives in vivo, the implementation of novel urinary biomarkers in in vitro studies seems to be unavoidable $[8,18,92]$.

\section{Novel Biomarkers for the In Vivo Nephrotoxic Effects of Mycotoxins}

As the incidence of acute kidney injury (AKI) and chronic kidney disease (CKD) is increasing worldwide, early identification and prompt intervention are needed to preserve the health of the patients. Traditional renal biomarkers, including estimated glomerular filtration rate (eGFR), blood urea nitrogen (BUN) and serum creatinine $(\mathrm{sCr})$ have been used to detect kidney failure, however, these markers are insensitive and rather non-specific. In order to detect early-stage renal injury, recent research has started to concentrate on more sensitive procedures than eGFR, BUN and $\mathrm{sCr}$ (see Figures 1 and 2). Using traditional methods to estimate kidney function, e.g., $\mathrm{sCr}$ in neonates and children, make clinical decisions difficult, because of variability in different stages of AKI [72,93]. Recently, new biomarkers have been described which reflect changes in the kidney at an early stage. In addition, genomic and proteomic technologies are also now available. Urinary level of novel biomarkers, like cystatin C, NGAL may indicate the severity of AKI in children [72].

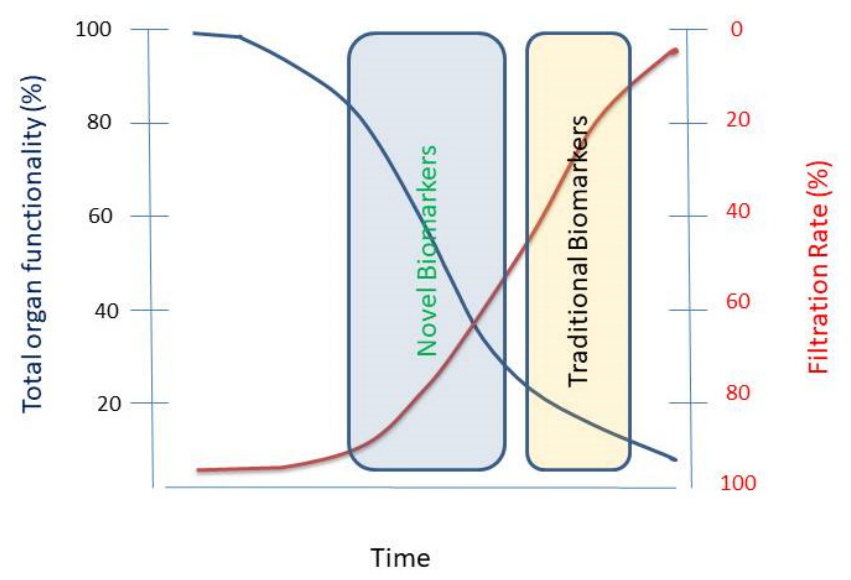

Figure 2. Schematic representation of sensitivity of traditional and novel biomarkers of nephrotoxicity. Filtration Rate (red line), the amount of blood filtered through the glomerulus per minute, is the clinical measure renal function (blue line). Unfortunately, the most widely accepted indicators of filtration rate lack sensitivity. Novel biomarkers have the potential of detecting damage before it becomes irreversible. Modified from [8].

Novel renal biomarkers are defined as parameters of physiological, chemical, structural, and genetic changes that show the severity, progress or presence of a histopathological alteration [94,95]. As an example, the Food and Drug Administration (FDA) and the European Medicines Agency have qualified KIM-1 to monitor the safety of drug in- 
duced nephrotoxicity [95]. We briefly introduce some molecules as potential biomarkers to monitor the toxic effects of mycotoxins on kidney.

$\beta_{2}$-microglobulin ( $\left.\beta_{2}-\mathrm{MG}\right)$ is a component of MHC class I molecules, and these protein complexes also incorporate $\alpha_{1}, \alpha_{2}$, and $\alpha_{3}$ proteins which are present on the surface of all nucleated cells. It is encoded by the B2M (human) and B2m (rat) genes and it has no transmembrane region, furthermore, $\beta_{2}-\mathrm{MG}$ associates with other molecules, like CD-1 or MR-1 [96]. This biomarker can be used to distinguish glomerular and tubular disorders in kidney, owing to the passage of $\beta_{2}$-MG through the glomeruli and their consecutive reabsorption by the renal proximal tubules. Under normal conditions, just minute quantities of $\beta_{2}-\mathrm{MG}$ are excreted in the urine, however, $\beta_{2}-\mathrm{MG}$ concentrations will increase when the renal tubules become damaged or diseased and, consequently, the efficiency of reabsorption becomes very low. On the contrary, when the glomeruli are damaged they are unable to filter out $\beta_{2}-\mathrm{MG}$, so the level of $\beta_{2}-\mathrm{MG}$ in the blood rises $[8,96]$. $\beta_{2}-\mathrm{MG}$ is still frequently used e.g., in heavy metal nephrotoxicity screening programs, although this biomarker is being replaced by other, more reliable markers, because of its instability in urinary samples at $\mathrm{pH}<7$ and its possible partial degradation before analysis [97].

$N$-acetyl- $\beta$-D-glucosaminidase (NAG) excretion is a sensitive indicator of proximal tubule injuries. It can be found in the lysosomes of proximal tubule epithelial cells. As it has a high molecular mass, $130 \mathrm{kDa}$, no NAG filtration occurs in the glomeruli, instead, it is released into the urine from dying or misfunctioning brush border cells as a result of tubular injury [98]. Nowadays, NAG is one of the most widely used biomarkers to diagnose renal tubular injury [98], and it is used routinely as a reference test in assessing renal tubular injuries in both human and in vivo animal nephrotoxicity models [99,100].

Kidney injury molecule- 1 (KIM-1) is a type 1 transmembrane glycoprotein encoded by the HAVCR1 (human) and Havcr1 (rat) genes. KIM-1a and KIM-1b are the two homologs in human, however, only KIM-1b is expressed in kidney orientated cells [94]. In a normal kidney, the expression level is relatively low, however, after renal tubular injury an increased expression can be detected. S3 segment of the proximal tubule is the locus where KIM-1 expression and synthesis reach the highest level [101]. After tubular injury, the membrane bound segment of KIM-1 is released in a metalloproteinase-dependent process, and the $90 \mathrm{kDa}$ peptide segment can be detected in the urine. As the expression of KIM-1 correlates with interstitial fibrosis and inflammation progression in the affected kidneys, making KIM-1 a sensitive biomarker [102]. The ectodomain is soluble in urine and is stable at room temperature as well, which provides KIM-1 based assays with good reliability and reproducibility [94].

Neutrophil gelatinase associated lipocalin (NGAL or siderocalin, lipocalin-2) is encoded by the LCN2 and Lcn2 (human and rat, respectively) genes and its expression can be detected in the loop of Henle and the collecting ducts. It protects the tubular epithelial cells from cell death by upregulating heme oxygenase-1 [102,103]. NGAL is among the top upregulated genes in damaged kidneys and a promising biomarker of tubular damage because this protein enters both serum and urine rapidly after the onset of AKI [104]. It can pass freely through the glomeruli as its molecular weight is $25 \mathrm{kDa}$, it is stable and resistant to protease degradation. Following filtration NGAL is retrieved by the proximal tubular cells by endocytosis [104].

Some other biomarker candidates have also been tested in recently $[105,106]$, including monocyte chemoattractant protein-1 (MCP-1), which is mainly produced by tubular epithelial cells, and is a member of the $\mathrm{C}-\mathrm{C}$ chemokine family. Among other potential applications, MCP-1 is considered to be a potential predictor of the degree of kidney fibrosis in IgA nephropathy patients [94]. Increased expression of the tissue inhibitor of metalloproteinases-1 (TIMP-1) may be indicative of the interstitial fibrosis of the kidneys [102].

In vitro nephrotoxicity studies using various kidney cell cultures, kidney models and in vivo studies with animal models are critically important to identify and validate novel 
renal injury biomarkers for human screening programs $[27,107]$. Nephrotoxicity studies carried out with mycotoxins have focused on OTA to date. As an example, the up-regulation of Kim-1, Timp-1, lipocalin 2, osteopontin, clusterin, vimentin and cyclooxygenase 2 genes have been reported in the kidneys of rats after long-term OTA exposures, potentiating the selection of future biomarkers to monitor OTA induced kidney injuries $[7,108,109]$. Increased urinary KIM-1 levels have been shown to correlate with subtle histopathological alterations in the kidneys in high OTA dose animal experiments [106]. The same study also reported elevated urinary $\beta_{2}-\mathrm{MG}$, cystatin $C$ and calbindin excretions in rat.

Understanding the nature and extent of FB1 nephrotoxicity is hampered by the paucity of human clinical and epidemiological data. Combining the study of established markers of FB1 exposure with nephrotoxicity biomarkers would be extremely useful in establishing the extent of the problem. Exposure to FB1 decreased cell viability, induced apoptosis and concomitantly upregulated the expression of KIM-1, collagen I, $\alpha$-SMA and TGF- $\beta_{1}$ in transformed human HK-2 cell cultures [110]. In addition, autophagy was activated after FB1 exposure, including the conversion of LC3 and up-regulation of ATGs, and the autophagy inhibitor 3-MA could block FB1-induced abnormalities. Antioxidant enzymes (Gpx1 and Gpx4) were downregulated, and intracellular ROS levels increased when the concentration of FB1 increased. FB1 induced autophagy in HK-2 cells [110], via autophagy mediated by mTORC1 instead of mTORC2 [110]. The expression of KIM-1 by HK-2 cells suggests that they are derived from the 33 proximal region of the nephron.

As mentioned before, in studies involving monitoring mycotoxin exposure and its consequences, focus has principally been on the metabolites and breakdown products of mycotoxins $[6,45,78,111,112]$. A mycotoxin "biomarker" basically means the quantification of mycotoxin molecules and their derivatives in blood, urine or breast milk [29]. For example a recent study in Bangladesh [112], CIT metabolites were checked but no kidney injury biomarkers, such as KIM-1, NAG, NGAL or $\beta_{2}$-MG were analyzed. A review in 2017 summarized the data available on different combinations of mycotoxins in biological matrices. In addition, studies focusing on OTA and its metabolites in the tested matrices, neither maternal nor infant urinary samples were checked for kidney biomarkers [66]. Furthermore, now it is a general protocol to take urine samples from the patients to detect mycotoxin exposure, but no indices of renal function are analyzed [88]. Since clinical laboratories facilities and methods are improving even in low GDP countries, introducing new, easy-to-use and affordable biomarker procedures would be very beneficial $[13,56,113]$.

\section{Biomarker Platform for Assay of Nephrotoxic Mycotoxins}

Mycotoxins may cause both acute and chronic disease, and the majority of mycotoxicoses will affect kidney function as well $[19,20,22,25,37,114]$. The most appropriate urinary biomarkers should be introduced into routine clinical laboratory protocols allowing estimation of the extent and localization of the renal injuries caused by mycotoxins. The characteristics of an ideal mycotoxin kidney injury biomarker should be as described below $[102,115,116]$. The assay should be noninvasive, sensitive, easy-to-perform and affordable for a routine laboratory, with easy access to samples, including urine and blood. The toxicological pathways behind the mycotoxin-triggered release of the candidate biomarkers should be clarified and related to the biomarker to increase the specificity of the assays $[90,117]$. Biomarker selection should follow the determination of whether it is most relevant for monitoring mycotoxin-induced AKI or CKD $[8,115,116]$. The latter would be especially important when the long-lasting, adverse physiological effects of chronic mycotoxin exposures are estimated. The selected biomarkers should provide the clinician with valuable information supplementing the routine information of mycotoxin metabolite tests and standard clinical laboratory assays currently available [105]. Monitoring mycotoxin intake and their adverse effect on renal functions would be particularly important for pregnant, breastfeeding mothers and their children $[59,66,68]$. Because of the accumulating evidence of mycotoxin carry-over from livestock to consumers, mycotoxin exposure of household animals should also be considered [30,118,119]. Biomarker assays 
could be incorporated into Good Feeding Practice to filter out those animals, which have been exposed to mycotoxin contaminated feed above tolerance limits.

The most widely used biomarkers in other fields are KIM1, NAG, NGAL and $\beta_{2^{-}}$ MG $[120,121]$. KIM-1 is a suitable marker for nephrotoxicity testing of drugs, and nowadays there is an increasing demand for KIM-1-based assays [101]. KIM-1 is generally measured by enzyme-linked immunosorbent assay (ELISA) or microparticle Luminex xMAP Technology assay [106]. Urinary NAG activity has been quantified either spectrofluorimetrically or spectrophotometrically using a wide-selection of substrates [71]. In order to measure NGAL, ELISA or a chemiluminescent microparticle immunoassay (CMIA) are available [106]. All these widely-used biomarkers indicate injuries at different segments of the proximal tubule (Figure 1) [102]. In a study on the effect of OTA in rats, possible early biomarkers were studied. The investigators singled out KIM-1 expression as putative marker of choice. In Table 2 we expand on this idea. The utility of biomarkers can be limited if there are not suitable methods for their measurement readily available. Hence, we include the common analytical tools for the markers suggested [7]. Consequently, a wide array of kidney parameters, including kidney biomarkers should be analyzed in parallel with mycotoxin metabolites $[7,60,112,122,123]$. A developed rapid test for the quantification of mycotoxins in urine could possibly combined with specific kidney injury tests would be a potential solution to test mycotoxin caused nephrotoxicity. Urinary NAG currently is the predominant enzyme assay used in industrial population screening programs and is well suited to screening in especially in low GDP countries. Use of fast KIM-1 tests including lateral-flow strip tests is particularly promising in developing countries $[120,121]$.

Mycotoxin exposure in the young may result in serious health problems and, hence, screening of neonates, infants and children for their renal function should be considered [60,124]. As the elevation of traditional biomarker levels, like $\mathrm{sCr}$ values, is typically indicative of renal insufficiencies, diagnosis of mycotoxin-elicited kidney injuries in neonates and infants seems to be difficult without the introduction of novel biomarkers [72]. Lowering mycotoxin exposure during intrauterine life could prevent premature birth and, as a consequence, would decrease the risk of the manifestation of AKI in neonates [69,125]. We suggest that a novel biomarker platform incorporating at some of the available NAG, NGAL, KIM-1, Cystatin C and/or TIMP-1 assays would help in the assessment of the progression of AKI in children [126]. Currently used laboratory procedures to screen for tubular damage resulting from mycotoxin damage are listed in Table 2. As there is a low amount of available data, the "Mycotoxins" column based on two findings: available publications, where biomarkers have been used so far or the affected kidney regions by the mycotoxin have been specified so far.

Table 2. Laboratory based assays that could be used to screen for renal tubular damage in affected populations.

\begin{tabular}{|c|c|c|c|}
\hline Biomarker & Mycotoxins & Technique(s) & References \\
\hline NGAL & OTA, AFB1, CIT & Immunoassays ELISA & {$[7,102,127]$} \\
\hline KIM-1 & OTA, AFB1, CIT & Immunoassays (ELISA, MSD-ECL) & {$[7,127-129]$} \\
\hline NAG & OTA, CIT & Enzymatic assays & [7] \\
\hline Cystatin C & OTA, AFB1, CIT & Immunoassays, ELISA & {$[7,105,127,129]$} \\
\hline L-FABP & OTA, CIT & Immunoassays, ELISA & [7] \\
\hline$\beta_{2}-\mathrm{MG}$ & OTA, CIT & Immunoassays, ELISA & [7] \\
\hline TIMP-1 & OTA & Immunoassays, ELISA & {$[7,129]$} \\
\hline clusterin & OTA & Immunoassays, ELISA & [7] \\
\hline osteopontin & OTA & Immunoassays, ELISA & [7] \\
\hline
\end{tabular}




\section{Concluding Remarks}

There is clearly a great potential benefit in detecting mycotoxin induced renal damage as early as possible and identifying the specific toxin involved. Combining detection of biomarkers of exposure with biomarkers of renal effects has the potential to prevent long term kidney damage and save lives. In spite of this, there are only very few recent publications involving urinary enzymes and mycotoxins together. Since the principal route of exposure is via contaminated food, it is important that the tests should be low cost and easily adapted to screen large populations. Kidney injury biomarkers are used to screen and monitor large populations exposed to nephrotoxins as well as to characterize the toxicological mechanism underlying their effect on the kidney. Screening programs should have both health and economic importance. Detection of mycotoxin-induced kidney injury at an early stage can allow intervention, thereby improving the health and the lives of people worldwide as well as reducing hospital costs. One of the objectives of the screening programs would be to develop easy to use point of care tests which would reduce the use of laboratory time and facilities. In addition, they would be suitable for use in developing countries which lack laboratory facilities. The established technology used in point of care testing could be utilized for screening. It should also be emphasized that certain mycotoxigenic microfungi, like the Aspergilli, are constantly moving north, which is still at relatively modest rate, but accelerating in the temperate zone in the northern hemisphere. It is time therefore to test urinary enzymes biomarkers to monitor mycotoxin-elicited renal damage in both household animals and humans. A combination of easy-to-use enzyme tests, e.g., NAG and KIM-1 with the direct assay of mycotoxins and their derivatives in urine would provide the best approach with which to determine both the effect and extent of exposure to mycotoxins and the detection of any nephrotoxic effects.

Author Contributions: Conceptualization, I.P., R.G.P., M.E.C.D., L.C. and Z.R.; writing-original draft preparation, Z.R., I.P., R.G.P., M.E.C.D. and L.C.; writing-review and editing, Z.R., I.P., R.G.P., M.E.C.D. and L.C.; funding acquisition, I.P., L.C., R.G.P. and M.E.C.D. All authors have read and agreed to the published version of the manuscript.

Funding: The publication was supported in Debrecen by the GINOP-2.3,2-15-2016-00062 project co-financed by the European Union and the regional Development Fund, by the Thematic Excel-lence Programme (TKP2020-IKA-04) of the Ministry for Innovation and Technology in Hungary, and Project no. 2018-1.2.1-NKP-2018-00002 has been implemented with the support provided from the National Research, Development and Innovation Fund of Hungary, financed under the 2018-1.2.1NKP funding scheme. Project no. TKP2020-IKA-04 has been implemented with the support provided from the National Research, Development and Innovation Fund of Hungary, financed under the 2020-4.1.1-TKP2020 funding scheme. Project no. K_137600 has been implemented with the support provided by the Ministry of Innovation and Technology of Hungary from the National Research, Development and Innovation Fund, financed under the K_21 funding scheme. The publication was supported through funding from The Kidney Fund, The Tom and Sheila Springer Trust, Epsom and St. Helier University Hospitals NHS Trust and Kidney Research (MD) and UK and the European Union STEP research programe (RGP).

Institutional Review Board Statement: Not applicable.

Informed Consent Statement: Not applicable.

Data Availability Statement: No new data were created or analyzed in this study. Data sharing is not applicable to this article.

Conflicts of Interest: The authors declare no conflict of interest. 


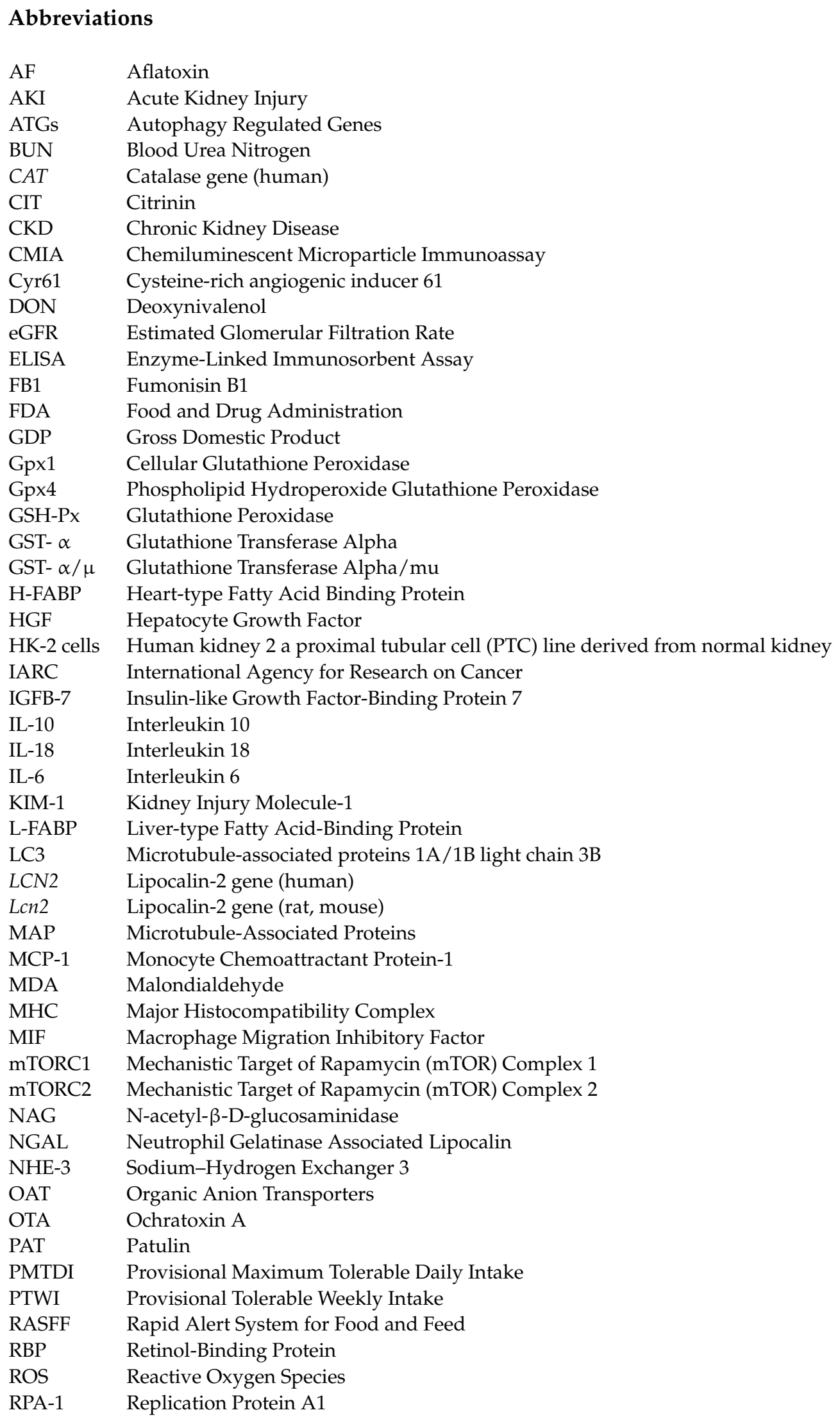




$\begin{array}{ll}\text { sCr } & \text { Serum Creatinine } \\ \text { STC } & \text { Sterigmatocystin } \\ \text { TFF-3 } & \text { Intestinal Trefoil Factor 3 } \\ \text { TGF- } \beta_{1} & \text { Transforming Growth Factor beta 1 } \\ \text { Timp-1 } & \text { Tissue Inhibitor of Metalloproteinase1 } \\ \text { VEGF } & \text { Vascular Endothelial Growth Factor } \\ \text { WHO } & \text { World Health Organization } \\ \text { ZEN } & \text { Zearalenone } \\ \alpha-S M A & \text { Smooth Muscle Alpha-Actin }\end{array}$

\section{References}

1. Barnett, L.M.A.; Cummings, B.S. Nephrotoxicity and renal pathophysiology: A contemporary perspective. Toxicol. Sci. 2018, 164, 379-390. [CrossRef]

2. Haque, M.A.; Wang, Y.; Shen, Z.; Li, X.; Saleemi, M.K.; He, C. Mycotoxin contamination and control strategy in human, domestic animal and poultry: A review. Microb. Pathog. 2020, 142, 104095. [CrossRef] [PubMed]

3. WHO Mycotoxins. Available online: https://www.who.int/news-room/fact-sheets/detail/mycotoxins (accessed on 10 October 2021).

4. Néstor Serra Gómez-Nicolau Mycotoxin Biomarkers: A Tool for Early Detection. Available online: https://www.allaboutfeed. net/all-about/mycotoxins/mycotoxin-biomarkers-a-tool-for-early-detection/ (accessed on 10 October 2021).

5. Nigam, S.K.; Wu, W.; Bush, K.T.; Hoenig, M.P.; Blantz, R.C.; Bhatnagar, V. Handling of drugs, metabolites, and uremic toxins by kidney proximal tubule drug transporters. Clin. J. Am. Soc. Nephrol. 2015, 10, 2039-2049. [CrossRef]

6. Debegnach, F.; Brera, C.; Mazzilli, G.; Sonego, E.; Buiarelli, F.; Ferri, F.; Rossi, P.G.; Collini, G.; De Santis, B. Optimization and validation of a LC-HRMS method for aflatoxins determination in urine samples. Mycotoxin Res. 2020, 36, 257-266. [CrossRef]

7. Rached, E.; Hoffmann, D.; Blumbach, K.; Weber, K.; Dekant, W.; Mally, A. Evaluation of putative biomarkers of nephrotoxicity after exposure to ochratoxin a in vivo and in vitro. Toxicol. Sci. 2008, 103, 371-381. [CrossRef]

8. Fuchs, T.C.; Hewitt, P. Biomarkers for drug-induced renal damage and nephrotoxicity-An overview for applied toxicology. AAPS J. 2011, 13, 615-631. [CrossRef]

9. Eshelli, M.; Qader, M.M.; Jambi, E.J.; Hursthouse, A.S.; Rateb, M.E. Current status and future opportunities of omics tools in mycotoxin research. Toxins 2018, 10, 433. [CrossRef]

10. Peles, F.; Sipos, P.; Győri, Z.; Pfliegler, W.P.; Giacometti, F.; Serraino, A.; Pagliuca, G.; Gazzotti, T.; Pócsi, I. Adverse Effects, Transformation and Channeling of Aflatoxins Into Food Raw Materials in Livestock. Front. Microbiol. 2019, 10, 1-26. [CrossRef] [PubMed]

11. Buszewska-Forajta, M. Mycotoxins, invisible danger of feedstuff with toxic effect on animals. Toxicon 2020, 182, 34-53. [CrossRef] [PubMed]

12. Ráduly, Z.; Szabó, L.; Madar, A.; Pócsi, I.; Csernoch, L. Toxicological and Medical Aspects of Aspergillus-Derived Mycotoxins Entering the Feed and Food Chain. Front. Microbiol. 2020, 10, 2908. [CrossRef] [PubMed]

13. Omotayo, O.P.; Omotayo, A.O.; Mwanza, M.; Babalola, O.O. Prevalence of Mycotoxins and Their Consequences on Human Health. Toxicol. Res. 2019, 35, 1-7. [CrossRef]

14. Wangia, R.N.; Tang, L.; Wang, J. Occupational exposure to aflatoxins and health outcomes: A review. J. Environ. Sci. Health Part C 2019, 37, 215-234. [CrossRef]

15. Viegas, C.; Fleming, G.T.A.; Kadir, A.; Almeida, B.; Caetano, L.A.; Gomes, A.Q.; Twarużek, M.; Kosicki, R.; Viegas, S.; Coggins, A.M. Occupational exposures to organic dust in irish bakeries and a pizzeria restaurant. Microorganisms 2020, 8, 118. [CrossRef]

16. Anfossi, L.; Giovannoli, C.; Baggiani, C. Mycotoxin detection. Curr. Opin. Biotechnol. 2016, 37, 120-126. [CrossRef] [PubMed]

17. Vidal, A.; Mengelers, M.; Yang, S.; De Saeger, S.; De Boevre, M. Mycotoxin Biomarkers of Exposure: A Comprehensive Review. Compr. Rev. Food Sci. Food Saf. 2018, 17, 1127-1155. [CrossRef]

18. Ali, N.; Degen, G.H. Biological monitoring for ochratoxin A and citrinin and their metabolites in urine samples of infants and children in Bangladesh. Mycotoxin Res. 2020, 36, 409-417. [CrossRef]

19. Malir, F.; Louda, M.; Ostry, V.; Toman, J.; Ali, N.; Grosse, Y.; Malirova, E.; Pacovsky, J.; Pickova, D.; Brodak, M.; et al. Analyses of biomarkers of exposure to nephrotoxic mycotoxins in a cohort of patients with renal tumours. Mycotoxin Res. 2019, 35, 391-403. [CrossRef] [PubMed]

20. Malir, F.; Ostry, V.; Pfohl-Leszkowicz, A.; Malir, J.; Toman, J. Ochratoxin A: 50 years of research. Toxins 2016, 8, 191. [CrossRef]

21. Ostry, V.; Malir, F.; Toman, J.; Grosse, Y. Mycotoxins as human carcinogens-the IARC Monographs classification. Mycotoxin Res. 2017, 33, 65-73. [CrossRef] [PubMed]

22. Reddy, L.; Bhoola, K.; Reddy, L.; Bhoola, K. Ochratoxins-Food Contaminants: Impact on Human Health. Toxins 2010, 2, 771-779. [CrossRef]

23. Heussner, A.; Bingle, L.; Heussner, A.H.; Bingle, L.E.H. Comparative Ochratoxin Toxicity: A Review of the Available Data. Toxins 2015, 7, 4253-4282. [CrossRef] [PubMed]

24. Zhu, L.; Zhang, B.; Dai, Y.; Li, H.; Xu, W.; Zhu, L.; Zhang, B.; Dai, Y.; Li, H.; Xu, W. A Review: Epigenetic Mechanism in Ochratoxin A Toxicity Studies. Toxins 2017, 9, 113. [CrossRef] 
25. Kőszegi, T.; Poór, M. Ochratoxin a: Molecular interactions, mechanisms of toxicity and prevention at the molecular level. Toxins 2016, 8, 111. [CrossRef]

26. Anzai, N.; Jutabha, P.; Endou, H. Molecular mechanism of ochratoxin A transport in the kidney. Toxins 2010, 2, 1381-1398. [CrossRef]

27. Schulz, M.C.; Schumann, L.; Rottkord, U.; Humpf, H.U.; Gekle, M.; Schwerdt, G. Synergistic action of the nephrotoxic mycotoxins ochratoxin A and citrinin at nanomolar concentrations in human proximal tubule-derived cells. Toxicol. Lett. 2018, 291, 149-157. [CrossRef]

28. Flajs, D.; Peraica, M. Toxicological properties of citrinin. Arh. Za Hig. Rada I Toksikol. 2009, 60, 457-464. [CrossRef]

29. Ali, N.; Degen, G.H. Citrinin biomarkers: A review of recent data and application to human exposure assessment. Arch. Toxicol. 2019, 93, 3057-3066. [CrossRef]

30. Ostry, V.; Malir, F.; Ruprich, J. Producers and important dietary sources of ochratoxin A and citrinin. Toxins 2013, 5, 1574-1586. [CrossRef]

31. Meerpoel, C.; Vidal, A.; Tangni, E.K.; Huybrechts, B.; Couck, L.; De Rycke, R.; De Bels, L.; De Saeger, S.; Van den Broeck, W.; Devreese, M.; et al. A Study of Carry-Over and Histopathological Effects after Chronic Dietary Intake of Citrinin in Pigs, Broiler Chickens and Laying Hens. Toxins 2020, 12, 719. [CrossRef] [PubMed]

32. Pfohl-Leszkowicz, A.; Molinie, A.; Tozlovanu, M.; Manderville, R. Combined Toxic Effects of Ochratoxin A and Citrinin, In Vivo and In Vitro. In ACS Symposium Series; ACS Publications: Washington, DC, USA, 2008; Volume 1001, pp. 56-79. ISBN 0-8412-6954-8.

33. Ben Salah-Abbès, J.; Belgacem, H.; Ezzdini, K.; Abdel-Wahhab, M.A.; Abbès, S. Zearalenone nephrotoxicity: DNA fragmentation, apoptotic gene expression and oxidative stress protected by Lactobacillus plantarum MON03. Toxicon 2020, 175, 28-35. [CrossRef] [PubMed]

34. Pal, S.; Singh, N.; Ansari, K.M. Toxicological effects of patulin mycotoxin on the mammalian system: An overview. Toxicol. Res. 2017, 6, 764-771. [CrossRef]

35. Jin, H.; Yin, S.; Song, X.; Zhang, E.; Fan, L.; Hu, H. P53 activation contributes to patulin-induced nephrotoxicity via modulation of reactive oxygen species generation. Sci. Rep. 2016, 6, 1-12. [CrossRef] [PubMed]

36. Marasas, W.F.O. Fumonisins: Their implications for human and animal health. Nat. Toxins 1995, 3, 193-198. [CrossRef]

37. Kouzi, S.A.; Wright, N.J.D.; Dirks-Naylor, A.; Uddin, M.N. Fumonisins: Effects on Human and Animal Health and Mechanisms of Toxicity. EC Pharmacol. Toxicol. 2018, 6, 187-208.

38. EFSA Scientific Opinion on the risk for public and animal health related to the presence of sterigmatocystin in food and feed. EFSA J. 2013, 11, 3254. [CrossRef]

39. Rushing, B.R.; Selim, M.I. Aflatoxin B1: A review on metabolism, toxicity, occurrence in food, occupational exposure, and detoxification methods. Food Chem. Toxicol. 2019, 124, 81-100. [CrossRef] [PubMed]

40. Wu, H.C.; Santella, R. The role of aflatoxins in hepatocellular carcinoma. Hepat. Mon. 2012, 12, e7238. [CrossRef]

41. Udovicki, B.; Audenaert, K.; De Saeger, S.; Rajkovic, A. Overview on the Mycotoxins Incidence in Serbia in the Period $2004-2016$. Toxins 2018, 10, 279. [CrossRef] [PubMed]

42. Naaz, F.; Abdin, M.Z.; Javed, S. Protective effect of esculin against prooxidant aflatoxin B 1-induced nephrotoxicity in mice. Mycotoxin Res. 2014, 30, 25-32. [CrossRef]

43. Mykkänen, H.; Zhu, H.; Salminen, E.; Juvonen, R.O.; Ling, W.; Ma, J.; Polychronaki, N.; Kemiläinen, H.; Mykkänen, O.; Salminen, S.; et al. Fecal and urinary excretion of aflatoxin B1 metabolites (AFQ1, AFM1 and AFB-N7-guanine) in young Chinese males. Int. J. Cancer 2005, 115, 879-884. [CrossRef]

44. JH, W.; TD, P.; PE, J.; JK, S.; CM, J.; Aggarwal, D. Human aflatoxicosis in developing countries: A review of toxicology, exposure, potential health consequences, and interventions. Am. J. Clin. Nutr. 2004, 80, 1106-1122.

45. Pfohl-Leszkowicz, A.; Manderville, R.A. Ochratoxin A: An overview on toxicity and carcinogenicity in animals and humans. Mol. Nutr. Food Res. 2007, 51, 61-99. [CrossRef]

46. Khan, M.A.; Asrani, R.K.; Iqbal, A.; Patil, R.D.; Rottinghaus, G.E.; Ledoux, D.R. Fumonisin B1 and ochratoxin A nephrotoxicity in Japanese quail: An ultrastructural assessment. Comp. Clin. Pathol. 2013, 22, 835-843. [CrossRef]

47. Grosman, M.E.; Elías, M.M.; Comin, E.J.; Rodriguez Garay, E.A. Alterations in renal function induced by aflatoxin B1 in the rat. Toxicol. Appl. Pharmacol. 1983, 69, 319-325. [CrossRef]

48. Kimanya, M.E.; Shirima, C.P.; Magoha, H.; Shewiyo, D.H.; De Meulenaer, B.; Kolsteren, P.; Gong, Y.Y. Co-exposures of aflatoxins with deoxynivalenol and fumonisins from maize based complementary foods in Rombo, Northern Tanzania. Food Control 2014, 41, 76-81. [CrossRef]

49. Anninou, N.; Chatzaki, E.; Papachristou, F.; Pitiakoudis, M.; Simopoulos, C. Mycotoxins' activity at toxic and sub-toxic concentrations:Differential cytotoxic and genotoxic effects of single and combined administration of sterigmatocystin, ochratoxin a and citrinin on the hepatocellular cancer cell line Hep3B. Int. J. Environ. Res. Public Health 2014, 11, 1855-1872. [CrossRef] [PubMed]

50. Hussein, H.S.; Brasel, J.M. Toxicity, metabolism, and impact of mycotoxins on humans and animals. Toxicology 2001, 167, 101-134. [CrossRef]

51. Klarić, M.S.; Rašić, D.; Peraica, M. Deleterious effects of mycotoxin combinations involving ochratoxin A. Toxins 2013, 5, 1965-1987. [CrossRef] [PubMed] 
52. Peraica, M.; Radić, B.; Lucić, A.; Pavlović, M. Toxic effects of mycotoxins in humans. Bull. World Health Organ. 1999, 77, 754-766.

53. Bryden, W.L. Mycotoxins in the food chain: Human health implications. Asia Pac. J. Clin. Nutr. 2007,16 (Suppl. 1), 95-101. [PubMed]

54. Fung, F.; Clark, R.F. Health effects of mycotoxins: A toxicological overview. J. Toxicol. Clin. Toxicol. 2004, 42, 217-234. [CrossRef]

55. Grenier, B.; Oswald, I. Mycotoxin co-contamination of food and feed: Meta-analysis of publications describing toxicological interactions. World Mycotoxin J. 2011, 4, 285-313. [CrossRef]

56. Ali, N.; Blaszkewicz, M.; Manirujjaman, M.; Degen, G.H. Biomonitoring of concurrent exposure to ochratoxin A and citrinin in pregnant women in Bangladesh. Mycotoxin Res. 2016, 32, 163-172. [CrossRef] [PubMed]

57. Milićević, D.; Nastasijevic, I.; Petrovic, Z. Mycotoxin in the food supply chain-Implications for public health program. J. Environ. Sci. Health Part C 2016, 34, 293-319. [CrossRef] [PubMed]

58. Gratz, S.W.; Currie, V.; Duncan, G.; Jackson, D. Multimycotoxin Exposure Assessment in UK Children Using Urinary BiomarkersA Pilot Survey. J. Agric. Food Chem. 2020, 68, 351-357. [CrossRef]

59. Khlangwiset, P.; Shephard, G.; Wu, F. Aflatoxins and growth impairment: A review. Crit. Rev. Toxicol. 2011, 41, 740-755. [CrossRef]

60. Lombard, M.J. Mycotoxin Exposure and Infant and Young Child Growth in Africa: What Do We Know? Ann. Nutr. Metab. 2014, 64 (Suppl. 2), 42-52. [CrossRef]

61. EC 1881/2006 Regulation 2006/1881 of the Commission of the European Communities of 19 December 2006 setting maximum levels for certain contaminants in foodstuffs. Off. J. Eur. Union 2006, 2006, 5-24.

62. EFSA English Edition. Official Journal of the European Union; Publications Office of the European Union: Luxembourg, 2019.

63. Kyei, N.N.A.; Boakye, D.; Gabrysch, S. Maternal mycotoxin exposure and adverse pregnancy outcomes: A systematic review. Mycotoxin Res. 2020, 36, 243-255. [CrossRef]

64. Crump, C.; Sundquist, J.; Winkleby, M.A.; Sundquist, K. Preterm birth and risk of chronic kidney disease from childhood into mid-adulthood: National cohort study. BMJ 2019, 365, 11346. [CrossRef]

65. Sangla, A.; Kandasamy, Y. Effects of prematurity on long-term renal health: A systematic review. BMJ Open 2021, 11, e047770. [CrossRef] [PubMed]

66. Ortiz, J.; Jacxsens, L.; Astudillo, G.; Ballesteros, A.; Donoso, S.; Huybregts, L.; De Meulenaer, B. Multiple mycotoxin exposure of infants and young children via breastfeeding and complementary/weaning foods consumption in Ecuadorian highlands. Food Chem. Toxicol. 2018, 118, 541-548. [CrossRef]

67. Magoha, H.; De Meulenaer, B.; Kimanya, M.; Hipolite, D.; Lachat, C.; Kolsteren, P. Fumonisin B1 contamination in breast milk and its exposure in infants under 6 months of age in Rombo, Northern Tanzania. Food Chem. Toxicol. 2014, 74, 112-116. [CrossRef]

68. Muñoz, K.; Blaszkewicz, M.; Campos, V.; Vega, M.; Degen, G.H. Exposure of infants to ochratoxin A with breast milk. Arch. Toxicol. 2014, 88, 837-846. [CrossRef]

69. Ojuri, O.T.; Ezekiel, C.N.; Eskola, M.K.; Šarkanj, B.; Babalola, A.D.; Sulyok, M.; Hajšlová, J.; Elliott, C.T.; Krska, R. Mycotoxin co-exposures in infants and young children consuming household- and industrially-processed complementary foods in Nigeria and risk management advice. Food Control 2019, 98, 312-322. [CrossRef]

70. Starr, M.C.; Charlton, J.R.; Guillet, R.; Reidy, K. Advances in Neonatal Acute Kidney Injury. Pediatrics 2021, 148, e2021051220. [CrossRef] [PubMed]

71. Csáthy, L.; Pócsi, I. Urinary N-Acetyl- $\beta$-D-glucosamimdase Determination in Newborns and Children: Methods and Diagnostic Applications. Clin. Chem. Lab. Med. 1995, 33, 575-588. [CrossRef]

72. Sethi, S.K.; Bunchman, T.; Chakraborty, R.; Raina, R. Pediatric acute kidney injury: New advances in the last decade. Kidney Res. Clin. Pract. 2021, 41, 40-51. [CrossRef]

73. Muñoz, K.; Cramer, B.; Dopstadt, J.; Humpf, H.U.; Degen, G.H. Evidence of ochratoxin A conjugates in urine samples from infants and adults. Mycotoxin Res. 2017, 33, 39-47. [CrossRef]

74. Al-Jaal, B.A.; Jaganjac, M.; Barcaru, A.; Horvatovich, P.; Latiff, A. Aflatoxin, fumonisin, ochratoxin, zearalenone and deoxynivalenol biomarkers in human biological fluids: A systematic literature review, 2001-2018. Food Chem. Toxicol. 2019, 129, 211-228. [CrossRef]

75. Cherkani-Hassani, A.; Mojemmi, B.; Mouane, N. Occurrence and levels of mycotoxins and their metabolites in human breast milk associated to dietary habits and other factors: A systematic literature review, 1984-2015. Trends Food Sci. Technol. 2016, 50, 56-69. [CrossRef]

76. Lumsangkul, C.; Chiang, H.-I.; Lo, N.-W.; Fan, Y.-K.; Ju, J.-C. Developmental Toxicity of Mycotoxin Fumonisin B1 in Animal Embryogenesis: An Overview. Toxins 2019, 11, 114. [CrossRef] [PubMed]

77. Zhang, K.; Flannery, B.M.; Oles, C.J.; Adeuya, A. Mycotoxins in infant/toddler foods and breakfast cereals in the US retail market. Food Addit. Contam. Part B 2018, 11, 183-190. [CrossRef] [PubMed]

78. Ali, N.; Blaszkewicz, M.; Alim, A.; Hossain, K.; Degen, G.H. Urinary biomarkers of ochratoxin A and citrinin exposure in two Bangladeshi cohorts: Follow-up study on regional and seasonal influences. Arch. Toxicol. 2016, 90, 2683-2697. [CrossRef]

79. Gruber-Dorninger, C.; Jenkins, T.; Schatzmayr, G. Global mycotoxin occurrence in feed: A ten-year survey. Toxins 2019, 11, 375. [CrossRef] 
80. Covarelli, L.; Beccari, G.; Marini, A.; Tosi, L. A review on the occurrence and control of ochratoxigenic fungal species and ochratoxin A in dehydrated grapes, non-fortified dessert wines and dried vine fruit in the Mediterranean area. Food Control 2012, 26, 347-356. [CrossRef]

81. Somma, S.; Perrone, G.; Logrieco, A. Diversity of black Aspergilli and mycotoxin risks in grape, wine and dried vine fruits The grape chain. Phytopathol. Mediterr. 2012, 51, 131-147. [CrossRef]

82. Perrone, G.; De Girolamo, A.; Sarigiannis, Y.; Haidukowski, M.E.; Visconti, A. Occurrence of ochratoxin A, fumonisin B2 and black aspergilli in raisins from Western Greece regions in relation to environmental and geographical factors. Food Addit. Contam. Part A Chem. Anal. Control Expo. Risk Assess. 2013, 30, 1339-1347. [CrossRef]

83. Arroyo-Manzanares, N.; Rodríguez-Estévez, V.; Arenas-Fernández, P.; García-Campaña, A.M.; Gámiz-Gracia, L. Occurrence of Mycotoxins in Swine Feeding from Spain. Toxins 2019, 11, 342. [CrossRef]

84. Rodrigues, I.; Handl, J.; Binder, E.M. Mycotoxin occurrence in commodities, feeds and feed ingredients sourced in the Middle East and Africa. Food Addit. Contam. Part B Surveill. 2011, 4, 168-179. [CrossRef]

85. Tang, E.N.; Ndindeng, S.A.; Bigoga, J.; Traore, K.; Silue, D.; Futakuchi, K. Mycotoxin concentrations in rice from three climatic locations in Africa as affected by grain quality, production site, and storage duration. Food Sci. Nutr. 2019, 7, 1274-1287. [CrossRef]

86. Commission, T.H.E.E. Scientific Opinion on the risks for public and animal health related to the presence of citrinin in food and feed. EFSA J. 2012, 10, 2013-2014. [CrossRef]

87. Degen, G.H.; Ali, N.; Gundert-Remy, U. Preliminary data on citrinin kinetics in humans and their use to estimate citrinin exposure based on biomarkers. Toxicol. Lett. 2018, 282, 43-48. [CrossRef] [PubMed]

88. Alassane-Kpembi, I.; Schatzmayr, G.; Taranu, I.; Marin, D.; Puel, O.; Oswald, I.P. Mycotoxins co-contamination: Methodological aspects and biological relevance of combined toxicity studies. Crit. Rev. Food Sci. Nutr. 2017, 57, 3489-3507. [CrossRef] [PubMed]

89. Assunção, R.; Pinhão, M.; Loureiro, S.; Alvito, P.; Silva, M.J. A multi-endpoint approach to the combined toxic effects of patulin and ochratoxin a in human intestinal cells. Toxicol. Lett. 2019, 313, 120-129. [CrossRef]

90. Sun, L.H.; Lei, M.Y.; Zhang, N.Y.; Gao, X.; Li, C.; Krumm, C.S.; Qi, D.S. Individual and combined cytotoxic effects of aflatoxin B1, zearalenone, deoxynivalenol and fumonisin B1 on BRL 3A rat liver cells. Toxicon 2015, 95, 6-12. [CrossRef] [PubMed]

91. Cristofori, P.; Zanetti, E.; Fregona, D.; Piaia, A.; Trevisan, A. Renal proximal tubule segment-specific nephrotoxicity: An overview on biomarkers and histopathology. Toxicol. Pathol. 2007, 35, 270-275. [CrossRef]

92. Heyndrickx, E.; Sioen, I.; Huybrechts, B.; Callebaut, A.; De Henauw, S.; De Saeger, S. Human biomonitoring of multiple mycotoxins in the Belgian population: Results of the BIOMYCO study. Environ. Int. 2015, 84, 82-89. [CrossRef]

93. Allegaert, K.; Smits, A.; van Donge, T.; van den Anker, J.; Sarafidis, K.; Levtchenko, E.; Mekahli, D. Renal Precision Medicine in Neonates and Acute Kidney Injury: How to Convert a Cloud of Creatinine Observations to Support Clinical Decisions. Front. Pediatrics 2020, 8, 1-10. [CrossRef]

94. Ntrinias, T.; Papasotiriou, M.; Balta, L.; Kalavrizioti, D.; Vamvakas, S.; Papachristou, E.; Goumenos, D.S. Biomarkers in Progressive Chronic Kidney Disease. Still a Long Way to Go. Prilozi 2019, 40, 27-39. [CrossRef] [PubMed]

95. Vaidya, V.S.; Ozer, J.S.; Dieterle, F.; Collings, F.B.; Ramirez, V.; Troth, S.; Muniappa, N.; Thudium, D.; Gerhold, D.; Holder, D.J.; et al. Kidney injury molecule-1 outperforms traditional biomarkers of kidney injury in preclinical biomarker qualification studies. Nat. Biotechnol. 2010, 28, 478-485. [CrossRef]

96. Li, L.; Dong, M.; Wang, X.G. The implication and significance of beta 2 microglobulin: A conservative multifunctional regulator. Chin. Med. J. 2016, 129, 448-455. [CrossRef]

97. Donaldson, M.D.C.; Chambers, R.E.; Woolridge, M.W.; Whicher, J.T. Stability of alpha1-microglobulin, beta2-microglobulin and retinol binding protein in urine. Clin. Chim. Acta 1989, 179, 73-77. [CrossRef]

98. Sheira, G.; Noreldin, N.; Tamer, A.; Saad, M. Urinary biomarker N-acetyl- $\beta$-D-glucosaminidase can predict severity of renal damage in diabetic nephropathy. J. Diabetes Metab. Disord. 2015, 14, 1-5. [CrossRef]

99. Satarug, S. Dietary cadmium intake and its effects on kidneys. Toxics 2018, 6, 15. [CrossRef] [PubMed]

100. Nakatani, S.; Nakatani, A.; Ishimura, E.; Toi, N.; Tsuda, A.; Mori, K.; Emoto, M.; Hirayama, Y.; Saito, A.; Inaba, M. Urinary iron excretion is associated with urinary full-length megalin and renal oxidative stress in chronic kidney disease. Kidney Blood Press. Res. 2018, 43, 458-470. [CrossRef]

101. Chen, R.; Sanyal, S.; Thompson, A.; Ix, J.H.; Haskins, K.; Muldowney, L.; Amur, S. Evaluating the Use of KIM-1 in Drug Development and Research Following FDA Qualification. Clin. Pharmacol. Ther. 2018, 104, 1175-1181. [CrossRef] [PubMed]

102. Wasung, M.E.; Chawla, L.S.; Madero, M. Biomarkers of renal function, which and when? Clin. Chim. Acta 2015, 438, 350-357. [CrossRef]

103. Bolignano, D.; Lacquaniti, A.; Coppolino, G.; Campo, S.; Arena, A.; Buemi, M. Neutrophil gelatinase-associated lipocalin reflects the severity of renal impairment in subjects affected by chronic kidney disease. Kidney Blood Press. Res. 2008, 31, 255-258. [CrossRef] [PubMed]

104. Schmidt-Ott, K.M. Neutrophil gelatinase-associated lipocalin as a biomarker of acute kidney injury-Where do we stand today? Nephrol. Dial. Transplant. 2011, 26, 762-764. [CrossRef]

105. Vanmassenhove, J.; Vanholder, R.; Nagler, E.; Van Biesen, W. Urinary and serum biomarkers for the diagnosis of acute kidney injury: An in-depth review of the literature. Nephrol. Dial. Transplant. 2013, 28, 254-273. [CrossRef]

106. Hoffmann, D.; Fuchs, T.C.; Henzler, T.; Matheis, K.A.; Herget, T.; Dekant, W.; Hewitt, P.; Mally, A. Evaluation of a urinary kidney biomarker panel in rat models of acute and subchronic nephrotoxicity. Toxicology 2010, 277, 49-58. [CrossRef] [PubMed] 
107. Lee, H.J.; Pyo, M.C.; Shin, H.S.; Ryu, D.; Lee, K.W. Renal toxicity through AhR, PXR, and Nrf2 signaling pathway activation of ochratoxin A-induced oxidative stress in kidney cells. Food Chem. Toxicol. 2018, 122, 59-68. [CrossRef]

108. Qi, X.; Yu, T.; Zhu, L.; Gao, J.; He, X.; Huang, K.; Luo, Y.; Xu, W. Ochratoxin A induces rat renal carcinogenicity with limited induction of oxidative stress responses. Toxicol. Appl. Pharmacol. 2014, 280, 543-549. [CrossRef] [PubMed]

109. Zhu, L.; Yu, T.; Qi, X.; Gao, J.; Huang, K.; He, X.; Luo, H.; Xu, W. Limited link between oxidative stress and ochratoxin A-Induced renal injury in an acute toxicity rat model. Toxins 2016, 8, 373. [CrossRef]

110. Hou, L.; Yuan, X.; Le, G.; Lin, Z.; Gan, F.; Li, H.; Huang, K. Fumonisin B1 induces nephrotoxicity via autophagy mediated by mTORC1 instead of mTORC2 in human renal tubule epithelial cells. Food Chem. Toxicol. 2021, 149, 112037. [CrossRef] [PubMed]

111. Escrivá, L.; Font, G.; Manyes, L.; Berrada, H. Studies on the Presence of Mycotoxins in Biological Samples: An Overview. Toxins 2017, 9, 251. [CrossRef] [PubMed]

112. Ali, N.; Blaszkewicz, M.; Mohanto, N.C.; Rahman, M.; Alim, A.; Hossain, K.; Degen, G.H. First results on citrinin biomarkers in urines from rural and urban cohorts in Bangladesh. Mycotoxin Res. 2015, 31, 9-16. [CrossRef] [PubMed]

113. Saha Turna, N.; Wu, F. Risk assessment of aflatoxin-related liver cancer in Bangladesh. Food Addit. Contam. Part A 2019, 36, 320-326. [CrossRef]

114. Díaz Nieto, C.H.; Granero, A.M.; Zon, M.A.; Fernández, H. Sterigmatocystin: A mycotoxin to be seriously considered. Food Chem. Toxicol. 2018, 118, 460-470. [CrossRef]

115. Schiffl, H.; Lang, S.M. Update on Biomarkers of Acute Kidney Injury. Mol. Diagn. Ther. 2012, 16, 199-207. [CrossRef]

116. Sirolli, V.; Pieroni, L.; Di Liberato, L.; Urbani, A.; Bonomini, M. Urinary peptidomic biomarkers in kidney diseases. Int. J. Mol. Sci. 2020, 21, 96. [CrossRef] [PubMed]

117. Wei, W.; Liu, C.; Ke, P.; Chen, X.; Zhou, T.; Xu, J.; Zhou, Y. Toxicological and physiological effects of successive exposure to ochratoxin A at food regulatory limits. Food Chem. Toxicol. 2021, 151, 112128. [CrossRef] [PubMed]

118. Benkerroum, N. Mycotoxins in dairy products: A review. Int. Dairy J. 2016, 62, 63-75. [CrossRef]

119. Veršilovskis, A.; De Saeger, S. Sterigmatocystin: Occurrence in foodstuffs and analytical methods-An overview. Mol. Nutr. Food Res. 2010, 54, 136-147. [CrossRef] [PubMed]

120. Van Duijl, T.T.; Soonawala, D.; de Fijter, J.W.; Ruhaak, L.R.; Cobbaert, C.M. Rational selection of a biomarker panel targeting unmet clinical needs in kidney injury. Clin. Proteom. 2021, 18, 1-14. [CrossRef]

121. Van Duijl, T.T.; Ruhaak, L.R.; de Fijter, J.W.; Cobbaert, C.M. Kidney Injury Biomarkers in an Academic Hospital Setting: Where Are We Now? Clin. Biochem. Rev. 2019, 40, 79-97. [CrossRef]

122. IARC. Chapter 5: Fetal and Neonatal Toxicities of Aflatoxins and Fumonisins. In Mycotoxin Control in Low- and Middle Income Countries; Wild, C.P., Miller, J.D., Groopman, J.D., Eds.; International Agency for Research on Cancer: Geneva, Switzerland, 2015; ISBN 9789283225102.

123. Bonerba, E.; Conte, R.; Ceci, E.; Tantillo, G. Assessment of dietary intake of patulin from baby foods. J. Food Sci. 2010, $75,25-27$. [CrossRef]

124. Sherif, S.O.; Salama, E.E.; Abdel-Wahhab, M.A. Mycotoxins and child health: The need for health risk assessment. Int. J. Hyg. Environ. Health 2009, 212, 347-368. [CrossRef]

125. Eze, U.A.; Routledge, M.N.; Okonofua, F.E.; Huntriss, J.; Gong, Y.Y. Mycotoxin exposure and adverse reproductive health outcomes in Africa: A review. World Mycotoxin J. 2018, 11, 321-339. [CrossRef]

126. Weidemann, D.K.; Weaver, V.M.; Fadrowski, J.J. Toxic environmental exposures and kidney health in children. Pediatric Nephrol. 2016, 31, 2043-2054. [CrossRef] [PubMed]

127. Díaz de León-Martínez, L.; Díaz-Barriga, F.; Barbier, O.; Ortíz, D.L.G.; Ortega-Romero, M.; Pérez-Vázquez, F.; Flores-Ramírez, R. Evaluation of emerging biomarkers of renal damage and exposure to aflatoxin-B 1 in Mexican indigenous women: A pilot study. Environ. Sci. Pollut. Res. 2019, 26, 12205-12216. [CrossRef]

128. Huen, S.C.; Parikh, C.R. Molecular phenotyping of clinical AKI with novel urinary biomarkers. Am. J. Physiol. Ren. Physiol. 2015, 309, F406-F413. [CrossRef] [PubMed]

129. Gunasekara, T.D.K.S.C.; De Silva, P.M.C.S.; Herath, C.; Siribaddana, S.; Siribaddana, N.; Jayasumana, C.; Jayasinghe, S.; CardenasGonzalez, M.; Jayasundara, N. The utility of novel renal biomarkers in assessment of chronic kidney disease of unknown etiology (Ckdu): A review. Int. J. Environ. Res. Public Health 2020, 17, 9522. [CrossRef] [PubMed] 